\title{
AN EMPIRICAL INVESTIGATION OF THE COMPETITIVE EFFECTS OF DOMESTIC AIRLINE ALLIANCES
}

\author{
Gustavo E. Bamberger \\ Dennis W. Carlton \\ Lynette R. Neumann
}

Working Paper 8197

http://www.nber.org/papers/w8197

\author{
NATIONAL BUREAU OF ECONOMIC RESEARCH \\ 1050 Massachusetts Avenue \\ Cambridge, MA 02138 \\ March 2001
}

We thank Robert Reynolds for helpful discussions. The views expressed herein are those of the authors and not necessarily those of the National Bureau of Economic Research.

(C) 2001 by Gustavo E. Bamberger, Dennis W. Carlton and Lynette R. Neumann. All rights reserved. Short sections of text, not to exceed two paragraphs, may be quoted without explicit permission provided that full credit, including (C) notice, is given to the source. 
An Empirical Investigation of the Competitive Effects of Domestic Airline Alliances

Gustavo E. Bamberger, Dennis W. Carlton and Lynette R. Neumann

NBER Working Paper No. 8197

March 2001

JEL No. L

\begin{abstract}
In this paper, we investigate empirically the effect of two recent domestic airline alliances. We find that both alliances benefited consumers - average fares fell and total traffic increased after the creation of the alliances on those city pairs affected by the alliances. We also find that these effects are found both on city pairs where the alliance created one or two new online carriers, and on city pairs where the alliance increased the service offered by one or both alliance partners. Finally, we find that the size of the fare effect of the alliance depends on the pre-alliance level of competition on a city pair with the effect being larger on those city pairs where the level of competition was relatively low.
\end{abstract}

Gustavo E. Bamberger

Lexecon Inc.

332 South Michigan Avenue

Chicago, IL 60604

Lynette R. Neumann

Lexecon Inc.

332 South Michigan Avenue

Chicago, IL 60604
Dennis W. Carlton

Graduate School of Business

University of Chicago

1101 East 58th Street

Chicago, IL 60637

and NBER 
Plans for three airline alliances involving the six largest domestic carriers in the United States were announced during the first half of 1998 . Continental Airlines and Northwest Airlines announced their intention to create an alliance in January 1998; Delta Airlines/United Airlines and American Airlines/US Airways followed in April 1998. An alliance allows the alliance partners to sell seats on each others' planes; each carrier can thereby offer additional airline service to potential travelers. For example, an alliance will allow a carrier to offer service on at least some city pairs that it does not fly between, by combining one leg of a flight on one of its planes with a second leg of a flight on which its alliance partner provides service.

The announcement of these alliances generated substantial controversy. The airlines claimed that the proposed alliances would benefit consumers, but others argued that the alliances would lead to a reduction in competition among domestic carriers. In October 1998, in response, at least in part, to concerns about the creation of these alliances, Congress granted the Department of Transportation the authority to delay alliances that the Department believes may have an anticompetitive impact on consumers. ${ }^{1}$ The Continental/Northwest alliance has gone forward, but the other two proposed deals have been abandoned or scaled back. ${ }^{2}$

Although the potential competitive effects of domestic airline alliances have recently received much attention, we are unaware of empirical research that addresses these issues. ${ }^{3}$ In this study, we investigate empirically the competitive effect of domestic airline alliances. In

1. Wald, Matthew L, "Guidelines on Airline Alliances Set," New York Times, section C, page 5, column 4, October 23, 1998 (late edition).

2. The Continental/Northwest alliance involved the acquisition of an equity stake in Continental by Northwest. The U.S. Department of Justice (" $\left.\mathrm{DOJ}^{\prime}\right)$ brought suit against Northwest, claiming that Northwest's partial ownership of Continental would reduce competition between the carriers on several city pairs. The DOJ's suit was resolved when Northwest divested its interest in Continental. The DOJ has not challenged the alliance agreement between Continental and Northwest. Cartton and Lexecon served as experts and submitted reports sponsored by Continental and Northwest.

3. A few studies have investigated the competitive effect of international alliances. See, for example, Brueckner and Whalen (1998); Oum, Park and Zhang (1996); U.S. General Accounting Office (1995); and U.S. Department of Transportation (1994). 
particular, we evaluate the effect of two domestic alliances that began in the mid-1990s - an alliance between Continental Airlines and America West Airlines and an alliance between Northwest Airlines and Alaska Airlines. Our key findings are:

- Both alliances provided substantial benefits to consumers. In particular, we find that average fares fell and total traffic increased between cities that were served by the alliances after the alliances began.

- These consumer benefits were generated both by the creation of new "online" carriers on some routes, and by allowing one or both of the alliance partners to increase the frequency of service on other routes.

- The magnitude of the alliance effect depends on the pre-alliance level of competition. This study is organized as follows. In Section I, we describe how airline alliances work and review the procompetitive justifications for, and anticompetitive concerns about, airline alliances. In Section II, we describe the Continental/America West and Northwest/Alaska alliances and our analysis of the effects of these alliances. In Section III, we show that both alliances benefited consumers.

\section{AIRLINE ALLIANCES.}

\section{A. How Airline Alliances Work.}

Airline alliances typically involve "code sharing," a practice in which a particular flight will receive the designations of two airlines in the computerized reservation systems ("CRSs") used by travel agents. ${ }^{4}$ Such a flight receives the code of the airline actually operating the flight the "operating carrier" - and the code of that carrier's alliance partner - the "marketing carrier." For example, prior to the code-share agreement between Continental and America West,

4. Some carriers enter only into "marketing alliances," which typically link frequent-flyer programs and provide travelers access to each other's airport lounges but do not include code sharing. The proposed American/US Airways deal was intended to begin as a 
America West (but not Continental) offered service between San Diego and Houston, and this flight was coded "HP" (America West's two-letter designation) on travel agent CRSs. Once the code-share agreement was in place, the flight between San Diego and Houston also appeared in CRSs with the Continental designation. That is, a single code-share flight appears twice on a CRS - it is listed once as a flight by the operating carrier and once as a flight by the marketing carrier (typically with a different flight number). The code-share flight between San Diego and Houston is designated $\mathrm{CO}^{*}$ (as well as HP), where the star $\left({ }^{*}\right)$ indicates that the flight is not operated by the marketing carrier. The use of the * to indicate such flights is mandated by a Department of Transportation regulation.

Code-share agreements allow a carrier to independently set price and sell service between cities that it otherwise would not be able to serve. For example, prior to the codeshare agreement, suppose that Continental offered non-stop service between cities A and B, but not between B and C, and that America West offered non-stop service between cities B and C, but not between A and B. Suppose also that neither carrier offered one-stop service between $A$ and $C$ through a connection point other than $B$. If America West's $B$ to $C$ flight were code shared with Continental, then Continental could offer $A$ to $C$ one-stop service. That is, Continental could quote a price, and offer service, between $A$ and $C$ (through $B$ ) - a passenger would fly on a Continental flight between A and B, and connect to the code-shared flight (i.e., the America West-operated flight) for the B to C leg of the trip. If the Continental A to B flight were code shared with America West, America West could offer one-stop service between A and C. Finally, if both flights were code shared, both Continental and America West could offer one-stop service between $A$ and $C$.

Absent the code-share agreement, a travel agent could sell a passenger a Continental ticket from $A$ to $B$ and an America West ticket from $B$ to $C$; the code-share agreement allows a

\section{(...continued)}

marketing alliance, with code sharing to be added later. 
travel agent to offer a Continental (or America West) "online" connection. That is, the one-stop code-share flight has many of the characteristics of "single-carrier" service (e.g., in terms of frequent flyer miles and assurance to consumers of coordinated baggage handling). Online connections typically are listed before "interline" itineraries by CRSs, and research shows that consumers prefer online to interline connections. ${ }^{5}$ Also, because online fares on a one-stop itinerary typically are lower than the sum of fares on the two flights making up an interline flight, online fares typically are lower than interline fares.

Code-share agreements also may allow a carrier to offer more frequent service between two cities. For example, suppose that Continental has three flights per day between cities $\mathrm{A}$ and $B$, but only one flight per day from $B$ to $C$. Thus, Continental could offer only one flight per day from $A$ to $C$ (through $B$ ). If America West has two flights per day between $B$ and $C$, and those flights are code shared with Continental, Continental may be able to offer up to three flights per day from $A$ to $C$ (depending on how the $A$ to $B$ and $B$ to $C$ flights are coordinated).

The financial arrangements between an operating carrier and its alliance partner can take different forms. In some alliances, the operating carrier determines seat availability and the marketing carrier sets prices for its service. ${ }^{6}$ This type of alliance is referred to as a "free sale" arrangement. Both the Continental/America West ("CO/HP") and Northwest/Alaska ("NWIAS") alliances are of this type. There is no fixed limit on how many seats the marketing carrier can sell. In these types of arrangements, all revenue from seats sold by the marketing carrier is kept by the operating carrier. For example, in a two-leg flight, such as $A$ to $B$ to $C$, where the first leg is operated by Continental and the second leg is operated by America West and codeshared with Continental, the total "through" fare from A to $\mathrm{C}$ would be prorated between the two

5. See Carlton, Landes and Posner (1980). Indeed, since deregulation, interline service has fallen from about 40 percent to about five percent of connecting trips. See Bamberger and Carlton (1996).

6. On some international alliances, alliance partners are granted antitrust immunity and thus are able to set fares jointly. This has not been true for alliances between major domestic carriers. 
carriers. If a passenger bought an $A$ to $C$ ticket (through $B$ ) from Continental, America West, as the operating carrier on $\mathrm{B}$ to $\mathrm{C}$, would receive all revenues allocated to the second leg; Continental would keep the revenue allocated to the A to $B$ leg. Although Continental receives no revenue associated with the $B$ to $C$ segment, Continental benefits from the code-share agreement to the extent that $A$ to $C$ travelers would use a different carrier to travel between $A$ to $C$ if an "online" connection had not been available through B (e.g., passengers could fly $A$ to $D$ to $B$ on a carrier that maintained a hub at D).

The marketing carrier determines the through fare. For example, if Continental sells an A to $\mathrm{C}$ ticket, it sets the price of that ticket and America West has no ability to affect that price. If both legs were code-shared, two $\mathrm{A}$ to $\mathrm{C}$ flights would be available - a Continental flight (CO on the $A$ to $B$ leg; $C O^{*}$ on the $B$ to $C$ leg) and an America West flight $\left(\mathrm{HP}^{*}\right.$ on the $A$ to $B$ leg; $H P$ on the $B$ to $C$ leg). Each carrier would set a price for a trip from $A$ to $C$ independently of its partner.

Alternatively, in a "blocked space" arrangement, the marketing carrier buys a block of seats on each code-share flight from the operating carrier. The marketing carrier attempts to sell those seats at whatever price it chooses and keeps the revenue from those sales. Because the number of seats purchased by the marketing carrier on any particular flight is fixed, either carrier may be "sold out" on a code-share flight while the other carrier has seats available on the same flight. Thus, for example, if Continental offered service between A and B, and purchased 10 seats from an alliance partner pursuant to a blocked space code-share agreement from $B$ to C, Continental would only be able to sell $10 \mathrm{~A}$ to $\mathrm{C}$ (through $\mathrm{B}$ ) tickets.

\section{B. Potential Competitive Effects of Airline Alliances.}

As we have discussed, the announcement of three major domestic airline alliances generated substantial controversy and resulted in Congressional action. However, the likely competitive effects of such domestic alliances have received relatively little attention from economists. Two recent studies - Brueckner (1997) and Park (1997) - develop models that 
analyze the likely effects of international alliances and find that code-sharing agreements may increase or reduce consumer welfare. However, both studies assume that the alliance partners set fares jointly on code-share flights, so the results of these models are not relevant to domestic alliances where joint fare setting typically does not take place. In this section of our paper, we discuss the potential procompetitive and anticompetitive effects of domestic alliances.

\section{Potential Procompetitive Effects.}

Airline alliances potentially can generate procompetitive effects in a variety of ways. First, as we have discussed, an airline alliance can create additional "online" carriers between two cities. If one carrier flies between $A$ and $B$, and another flies between $B$ and $C$, an alliance between the two carriers can create one or two additional competitors between $A$ and $C$. In addition, the alliance partners may be able to coordinate their schedules so that better connections are created at airport B. Furthermore, in any event, when a single firm sets one through price, any double marginalization issues that arise from pricing $A$ to $B$ and $B$ to $C$ separately disappear so that the through price should fall. (See Brueckner (1997).)

Second, an airline alliance can improve a carrier's service offerings between two cities by allowing the alliance partners to offer more frequent service. In an example we discussed earlier, an alliance between a carrier that flies from $A$ to $C$ (through B) and a partner that flies from $B$ to $C$ allowed the first carrier to offer more frequent $A$ to $C$ service.

Third, an alliance may allow the alliance partners to reduce costs in a variety of ways. Some possible ways include the joint use of certain airport facilities, such as lounges, gates and check-in counters, together with joint advertising and promotion. Such cost reductions could make the alliance carriers more effective competitors. (See Park (1997).)

Fourth, an alliance could increase competition by allowing two carriers to market the same seat. In a prior example, both $\mathrm{CO}$ and HP could compete to sell the same seat to a passenger flying $A$ to $C$ (through $B$ ). That is, a passenger could choose between flying on 
Continental (CO on the A to B leg, and $\mathrm{CO}^{\star}$ on the $\mathrm{B}$ to $\mathrm{C}$ leg) or on America West (HP* on the A to $B$ leg, and HP on the B to $C$ leg), even though the two offerings are, in effect, the same seat.

\section{Potential Anticompetitive Effects.}

Some industry observers have argued that airline alliances can reduce competition. First, alliances could harm consumers because of their effect on how flight information is displayed on CRS screens. Code-share flights are listed at least twice on a CRS; if connections are involved, the same flight may be listed three times (once as an online flight for each of the alliance partners and once as an interline flight). Thus, some critics of airline alliances argue that alliances lead to rivals' flights being "crowded out" of the first CRS screen viewed by travel agents. For example, the GAO reports that "[t]ravel agents overwhelmingly tend to book customers on flights listed on the first screen." The GAO claims that "[a]s a result, listings of connecting code-share flights several times limit competition and reduce consumers' choices" (p. 54). ${ }^{7}$ In response to such concerns, the European Union has limited the display of a codeshare flight on a CRS to at most two since 1993. The U.S. Department of Transportation, however, does not impose such limits on CRS displays.

Second, an airline alliance could reduce competition that otherwise would have occurred between carriers if the creation of the alliance reduced either partner's incentive to expand its service either between city pairs it already served or to other city pairs. That is, in the absence of the alliance, one or both alliance partners might have increased service by adding capacity.

7. The chairman and CEO of TWA reportedly claimed that the three domestic airline alliances announced in 1998 were anti-competitive because having the same flight listed twice on CRSs could deceive consumers. See Zuckerman, Laurence, "T.W.A. Chairman Critical of 'Anti-Competitive' Airline Alliances," New York Times, section C, page 4, column 3, September 17, 1998 (late edition). 
As a result of the alliance, however, that capacity expansion may not be needed since the airline instead relies on its alliance partner's capacity.

Third, an alliance could increase "multi-market" contact between the alliance partners and other carriers. Evans and Kessides (1994) argue that an increase in multi-market contact between carriers reduces competition between them.

We do not address the second two potential anticompetitive effects of alliances in this study. However, we note that the second reason - a reduction in the incentive to expand service - will generally be difficult to evaluate. In effect, a claim about reduced incentives to enter a city pair is a claim about the "actual potential competition" doctrine - a doctrine that U.S. courts have generally not accepted in the absence of some explicit evidence of intent to enter. Moreover, the third reason - an alliance increases "multimarket contact" - seems strained because it implies that the introduction of a new competitor on a route (e.g., A to B to $C$ ) is undesirable because it provides an opportunity for a carrier to use that route to discipline a rival elsewhere if competition between the carriers becomes severe. Furthermore, the multimarket contact hypothesis does not, in general, predict that the alliance would have a differential impact on fares on city pairs affected by the alliance than on other city pairs. Thus, a finding that an alliance leads to lower fares suggests that a multimarket contact effect on fares, if any, is small relative to increases in competition resulting from the alliance.

\section{THE CONTINENTALIAMERICA WEST AND NORTHWESTIALASKA ALLIANCES.}

We investigate the competitive effects of the Continental/America West ("CO/HP") and Northwest/Alaska ("NWIAS") alliances with a series of "before-and-after" regression studies. That is, we compare changes in average fares and total traffic from a period before the alliance was instituted to a period after the alliance was in place on city pairs affected by an alliance which we refer to as "alliance pairs" - to the corresponding changes on a set of benchmark city pairs not affected by the alliances - which we refer to as "non-alliance pairs." 
Both alliances include an agreement to code share on specific "segments." There is a distinction between a segment and a city pair. A segment consists of a non-stop flight between two airports; thus, a one-stop flight consists of two segments. In contrast, a "city pair" refers to the two cities between which a passenger travels. For passengers flying non-stop between two cities, segments are equivalent to city pairs. However, passengers who make connections travel on two (or more) segments none of which is the same as the city pair between which the passengers fly between. ${ }^{8}$

As we have discussed, the segment San Diego-Houston is an America West flight that was code shared with Continental. Code sharing between Continental and America West began on several segments on October 1, 1994 (additional code-share segments were added to the CO/HP alliance over the next several months). By May 1995, Continental had placed its code on about 90 America West segments and America West had placed its code on about 40 Continental segments. ${ }^{9}$ The third quarter of 1994 - the last quarter before the alliance began is the "before" period for our analysis of the CO/HP alliance; the third quarter of 1995 - one year later - is the "after" period. ${ }^{10}$

Because the NWIAS alliance was put in place over a longer period than the CO/HP alliance, we use the third quarters of 1994 and 1996 as the "before-and-after" period for our analysis of the NWIAS alliance. Code sharing began on a few segments in the third quarter of 1995; a substantial number of code-share segments were added to the alliance over the next

8. For example, the itinerary Hartford-Houston-San Diego consists of two segments (HartfordHouston and Houston-San Diego) that comprise one city pair (Hartford-San Diego). The same city pair can reflect different combinations of segments (e.g., the segments HartfordChicago and Chicago-San Diego also can be used to fly the city pair Hartford-San Diego).

9. Seven segments were "double coded" - both carriers flew on the segment and both carriers put their code on their partners' flights. These double-coded segments were flights from a hub of one carrier to a hub of its partner (e.g., Las Vegas, an America West hub, to Houston, a Continental hub).

10. The data we rely on are available only on a quarterly basis. We compare third quarters to control for any season-specific effects. 
two years. By the third quarter of 1996, Northwest had placed its code on about 45 Alaska segments; Alaska had placed its code on about 10 Northwest segments.

We identify potential alliance pairs as those city pairs for which the code-share agreement converts a potential interline flight between Continental and America West (or Northwest and Alaska) into a code-share flight. For example, because Hartford-Houston is a Continental segment, and the segment Houston-San Diego is an America West flight that was code-shared with Continental, the route Hartford-Houston-San Diego is a potential code-share route created by the alliance. Thus, San Diego-Hartford is a potential alliance pair for the CO/HP alliance. ${ }^{11}$ For the purpose of our analysis, we treat such city pairs as alliance pairs if at least one passenger was reported as flying on one of the alliance partners over a code-share route between the two cities in the post-alliance period. ${ }^{12}$ A substantial number of segments were code shared, so a large number of potential code-share connecting flights were created by the alliance. ${ }^{13}$

11. For the NWIAS agreement, the ability of Alaska to code-share was "turned off" on selected city pairs. For example, if the alliance generated an online routing from airport $A$ to $B$ to $C$ for Alaska, but Northwest already flew a non-stop from $A$ to $C$, the routing $A$ to $B$ to $C$ sometimes was "turned off" and could not be offered for sale by Alaska. In such cases, we treat the city pair A-C as a non-alliance pair. Such pairs were identified for us by Northwest.

12. This screen eliminates itineraries not actually flown by passengers. For example, the city pair San Francisco to Los Angeles would not be treated as an alliance pair even if San Francisco-Honolulu-Los Angeles were a potential code-share routing unless one passenger actually flew San Francisco-Honolulu-Los Angeles on Continental or America West in the post-alliance period. Our procedure is conservative in that it may classify as alliance pairs city pairs where the alliance partners did not, in the minds of consumers, offer online service even though one or a few passengers flew that route. Thus, our average measured alliance effects likely reflect results from alliance pairs and (misclassified) non-alliance pairs.

13. For example, if $A$ to $B$ is code shared, and if $B$ is a hub airport for one of the alliance partners with flights to 50 cities $C 1$ to $C 50$, then the code-share agreement could create up to fifty new online connections - A to $B$ to $C 1$ through $A$ to $B$ to $C 50$. Furthermore, if all possible "double connects" are considered - i.e., a three-segment flight such as $A$ to $B$ to $C$ to $D$ - the number of possible new online connections can be very large. Because traffic on double connects is primarily concentrated though hubs, we limit our analysis of double connects in the CO/HP analysis to only those flights where the middle segment is one of the "double coded" segments discussed in footnote 11. For the NWIAS alliance, we assume that all double-connect routings include a stop in a Northwest hub (i.e., if a flight is $A$ to $B$ to $C$ to $D$, we limit alliance pairs to flights where $B$ or $C$ is Detroit, Memphis or Minneapolis). Even for the double connect alliance pairs we identify, most of these city pairs do not have enough traffic to pass the total traffic screen we use to choose our sample (which we discuss in the next section of this paper). 
If $A$ to $B$ to $C$ is an online connection created by the alliance that was flown by at least one passenger, we treat $A$ to $C$ as an alliance pair even if one of the alliance partners offered non-stop or connecting service (through a different airport) between $A$ and $C$ in the pre-alliance period. That is, we treat $A$ to $C$ as an alliance pair because the alliance created additional service between $A$ and $C$ (e.g., it created an alternate online routing between $A$ and $C$ ), which may benefit consumers.

The non-alliance pairs included in our analysis are city pairs not affected by the alliance on which one of the alliance partners reported passengers in the pre- or post-alliance periods. ${ }^{14}$ The unit of observation for our analysis is a city pair - that is, we investigate the effect of the alliance on the average fare paid to, and traffic carried by, all carriers on the alliance pairs. ${ }^{15}$ We investigate the effect of the alliances on both fares and traffic because a carrier's average fare reflects a wide variety of fares. Thus, a decline in average fare on a route need not be associated with an increase in total traffic on that route. For example, a decrease in average price may reflect a decline in "business" fares and an increase in "leisure" fares. Depending on the relative elasticities of demand for each type of ticket, total traffic could increase or decrease in response to such fare changes.

\section{FINDINGS.}

In this section, we discuss our findings on (1) the effect of each alliance on average fares and total traffic; (2) the extent to which the alliance effect differs between alliance pairs where the alliance created additional online competitors and alliance pairs where the alliance created additional online service but did not increase the number of online rivals; and (3) the extent to which the magnitude of the alliance effect varied with the level of pre-alliance competition on a city pair. Our analysis of the last two issues is limited to the CO/HP alliance

14. That is, we exclude from our analysis city pairs for which neither partner offered service. 15. In some cases, the alliance created new city pairs for the alliance partners - thus, there is 
because the CO/HP alliance affected a substantially larger number of city pairs than the NW/AS alliance.

\section{A. Base Model.}

We estimate the effect of each alliance with a series of regression models. ${ }^{16}$ The dependent variables for our regression models are the percentage changes in fares and traffic from the pre-alliance period to the post-alliance period. That is, the dependent variables in our models are:

(1) In(average fare post alliance $_{\text {average fare }}$ prealliance);

(2) In(total traffic post-alliance $/$ total traffic $c_{\text {prealliance). }}{ }^{17}$

We treat several potential explanatory variables as exogenous:

(1) ALLIANCE DUMMY - a dummy variable that indicates whether the city pair is an alliance pair;

(2) CHANGE IN PERCENT ROUND TRIP - the change in the percentage of passengers flying on round-trip tickets; and

(3) ENTRY BY SOUTHWEST - a dummy variable that indicates entry by Southwest Airlines during the alliance period (defined as one if Southwest's passenger share on a city pair was greater than or equal to five percent in the post-alliance period and less than five percent in the pre-alliance period; zero otherwise).

Two other potential explanatory variables - the change in the percentage of passengers flying direct between two cities; ${ }^{18}$ and the change in concentration on the city pair, likely will be affected by the creation of the alliance. For example, if the alliance creates better connections,

\section{(...continued)}

no "before" price or output for the alliance partners on these city pairs.

16. Our analysis is based on information compiled by Data Base Products, Inc., which derives its information from the Department of Transportation's Data Banks $1 \mathrm{~A}$ and $298 \mathrm{C}$. Both data bases are 10 percent samples of all tickets flown during a quarter. Data Bank $1 \mathrm{~A}$ is based on information provided by major carriers; Data Bank 298C contains information on commuter airlines.

17. We also investigate the effect of the alliance on the partners' combined city pair share. In general, we find that the partners' combined share increased on alliance pairs relative to non-alliance pairs by a statistically significant amount.

18. A direct flight is one with no change of plane. Thus, all non-stop flights are direct, and a few connecting flights are direct. The Department of Transportation data bases do not 
the advantage of non-stops over one-stop flights on a particular flight could be reduced, which would affect the proportion of passengers taking direct flights between two cities. Similarly, if the alliance makes one or both alliance partners more effective competitors on a particular city pair, the alliance partners' share of passengers on that city pair could increase, which would affect measured concentration on that route.

To reduce potential endogeneity concerns with these last two potential explanatory variables, we measure both variables using information only from non-alliance carriers. For example, suppose that prior to the alliance, 100 passengers flew between $A$ and $B$. Assume that ten of these passengers flew on one of the alliance carriers, and that of the 90 non-alliance passengers, 45 flew on direct flights. Now suppose that in the after period, total traffic increases to 105 , the alliance partners have 20 passengers, and 50 of the non-alliance passengers flew on direct flights, so that the percentage of non-alliance traffic that flew on direct flights in the post-alliance period is 59 percent (i.e., 50 out of 85 ). We define the change in percentage nonalliance direct as the difference between the pre- and post-alliance percentage non-alliance direct adjusted for the non-alliance share of traffic. In this example, the change in percentage non-alliance direct is 59 percent minus 50 percent, times 0.90 (i.e., the pre-alliance non-alliance share), or about eight percent.

Similarly, we measure change in concentration $(\mathrm{HHI})$ on a city pair using non-alliance carrier information..$^{19}$ Suppose that in the pre-alliance period, total traffic on a city pair was 100 passengers, with 10 being carried by one of the alliance partners and the remaining 90 being split equally between two non-alliance carriers. Then the "non-alliance $\mathrm{HHI}$ " in this period would equal 5,000 (i.e., because two carriers each had a 50 percent share of non-alliance

(...continued) distinguish between non-stop and direct flights.

19. Change in concentration over time is only a rough measure of the change in competitive conditions on a route for several reasons, including because it ignores changes in total capacity in the route. For example, if the largest carrier on a route expands capacity, measured $\mathrm{HHI}$ will increase, but that increase does not indicate a reduction in competition. 
passengers). Now suppose that in the post-alliance period, total traffic equaled 105

passengers, with the alliance carriers having 20 passengers, and the remaining passengers being accounted for by one carrier with 50 passengers and a second carrier with 35 passengers. Then the "non-alliance $\mathrm{HHI}$ in the post-alliance period would equal 5,156 (50/85 squared plus $35 / 85$ squared). We define the change in non-alliance $\mathrm{HHI}$ as the difference between the pre- and post-alliance non-alliance HHIs, adjusted for the non-alliance share of traffic. In this example, the change in non-alliance $\mathrm{HHI}$ is 5,156 minus 5,000 , times 0.90 , or $140 .^{20}$

We therefore include as potential explanatory variables:

(4) CHANGE IN PERCENT NON-ALLIANCE DIRECT - the change in the percentage of non-alliance passengers flying direct, adjusted for the non-alliance share of traffic; and

(5) CHANGE IN CITY PAIR NON-ALLIANCE HHI - the change in the passengerbased city pair non-alliance $\mathrm{HHI},{ }^{21}$

Finally, because the dependent variables are in first-difference form, our model implicitly controls for time-invariant city-pair specific effects, such as the distance between the endpoint cities and the average mix over time of business and tourist travel on the city pair. ${ }^{22}$

\section{Effect of Alliances on Fares.}

For the CO/HP alliance, our analysis is based on city pairs that had total traffic of at least 10 (one-way) passengers per day in both the third quarter of 1994 and the third quarter of $1995 .^{23}$ This sample consists of 3,603 city pairs; 709 of these are alliance pairs. ${ }^{24}$ We find that

20. Our results are not substantially different if we use versions of these variables based on all carriers (i.e., including the alliance partners).

21. City pair shares are based on all single-line passengers; i.e., we exclude intertine traffic from the $\mathrm{HHI}$ calculations.

22. Our specification is thus similar to one used by Evans, Froeb and Werden (1993), who use a pooled time-series cross-section approach with fixed effects, the percentage of passengers flying direct; the percentage of passengers flying round trip; and city pair $\mathrm{HHI}$ (all in levels) as regressors.

23. That is, we include only city pairs that had more than 90 (sample) one-way passengers in 
fares on the alliance pairs fell substantially and by a statistically significant amount after the alliances were put in place.

Table 1 reports the results of our regressions on average fares for the CO/HP alliance. The first column reports the results of a model that includes only a dummy variable for the alliance. We find that fares on alliance pairs fell 8.4 percent as compared to non-alliance pairs between the third quarters of 1994 and $1995 .^{25}$ The second column reports the results of adding three additional explanatory variables - CHANGE IN PERCENT NON-ALLIANCE DIRECT, CHANGE IN PERCENT ROUND TRIP and ENTRY BY SOUTHWEST. These variables add substantial explanatory power to the regression. For example, we find that fares fell substantially (by about 21 percent) between the third quarters of 1994 and 1995 on those city pairs where Southwest entered. However, adding these variables does not substantially change the estimated effect of the alliance - in this specification, we find fares on the alliance pairs fell relative to the non-alliance pairs by about 7.5 percent.

The third column of Table 1 adds CHANGE IN CITY PAIR NON-ALLIANCE HHI as an explanatory variable. We find that increases in CHANGE IN CITY PAIR NON-ALLIANCE HHI increase fares by about 1.6 percent for every 1,000 point increase in $\mathrm{HHI}$. Again, however, adding this regressor does not substantially change the estimated alliance effect (about -7.4 percent).

The NWIAS alliance involves many relatively low-traffic city pairs because many of the segments served by Alaska have an Alaskan airport as one endpoint. For this reason, using a

(...continued) both quarters; 91 sample passengers imply 910 total passengers, or about 10 one-way passengers per day for a quarter. We also repeated our analysis using different total traffic cutoffs (20 one-way passengers per day, and one one-way passenger per day). Our results are not substantially different when we use different total traffic screens.

24. These 3,603 city pairs accounted for about 72 percent of total U.S. domestic traffic in the third quarter of 1995.

25. Unless noted otherwise, all regression coefficient estimates reported in the text are statistically significant at the five percent level. Because we find evidence of heteroscedasticity, we report (in the tables) t-statistics that are based on White's method of estimating the 
Table 1

CO/HP Base Model Results - Change in Fares

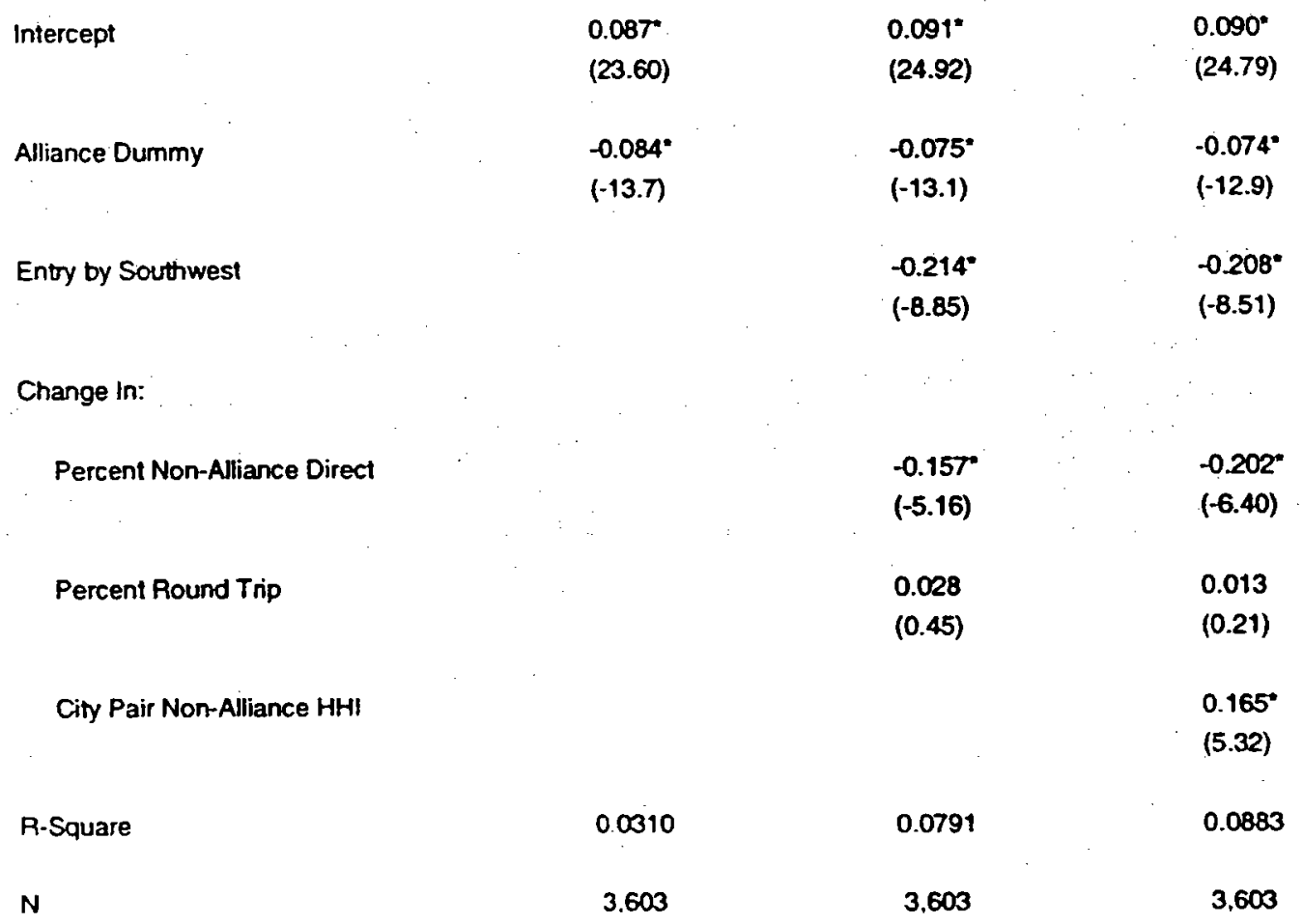

- Statistically significant at the five percent level.

Notes: White-adjusted t-statistics reported in parentheses.

City pairs with fewer than 10 passengers per day are excluded.

Results are based on the 3rd quarters of 1994 and 1995.

Source: Data Base Products Inc.; Continental. 
relatively high traffic level cutoff will eliminate from our analysis many of the city pairs affected by the NWIAS alliance. We thus base our analysis of the NWIAS alliance on a lower traffic cutoff level - we use a cutoff of at least five (one-way) passengers per day in both the third quarter of 1994 and the third quarter of $1996 .^{26}$ For example, the alliance pairs FairbanksKansas City (connecting through, for example, Seattle and Minneapolis) and Juneau-Minneapolis (connecting through Seattle) pass a five-passenger screen but would be excluded using a 10-passenger cutoff. This sample consists of 5,884 city pairs, of which 170 are alliance pairs. ${ }^{27}$

Our findings for the NWIAS alliance are similar to our findings for the CO/HP alliance the alliance is associated with a substantial and statistically significant reduction in average fares. We find that fares on the NWIAS alliance pairs fell substantially between the third quarters of 1994 and 1996 as compared to the change in fares on non-alliance pairs during the same period. Table 2 reports the results of our regressions on average fares for the NWIAS alliance. Based on a model that includes only a dummy variable for the alliance, fares on alliance pairs fell 3.9 percent as compared to fares on non-alliance pairs between the third quarters of 1994 and 1996. See column 1 of Table 2.

The second column reports the results of adding CHANGE IN PERCENT NONALLIANCE DIRECT, CHANGE IN PERCENT ROUND TRIP and ENTRY BY SOUTHWEST. As in our CO/HP analysis, these variables add substantial explanatory power to the regression. For example, ENTRY BY SOUTHWEST in this sample is associated with a decline in fares of about 33 percent. Adding these variables has little effect on the estimated effect of the alliance

(...continued) appropriate variance-covariance matrix of the estimated coefficients.

26. We also repeated our analysis using different total traffic cutoffs (10 one-way passengers per day, and one one-way passenger per day). Our results suggest that the NWIAS alliance had a larger effect on relatively low-traffic city pairs than on higher-traffic city pairs.

27 . These 5,884 city pairs accounted for about 70 percent of total U.S. domestic traffic in the third quarter of 1996. 
Table 2

NW/AS Base Model Results - Change in Fares

\begin{tabular}{|c|c|c|c|}
\hline Intercept & $\begin{array}{l}0.041^{\circ} \\
(13.77)\end{array}$ & $\begin{array}{l}0.051^{\circ} \\
(16.82)\end{array}$ & $\begin{array}{l}0.051^{*} \\
(16.57)\end{array}$ \\
\hline Alliance Durnmy & $\begin{array}{l}-0.039= \\
(-3.23)\end{array}$ & $\begin{array}{l}-0.046^{*} \\
(-3.84)\end{array}$ & $\begin{array}{l}-0.047 \\
(-3.91)\end{array}$ \\
\hline Entry by Soutthwest & & $\begin{array}{l}-0.337^{\circ} \\
(-17.9)\end{array}$ & $\begin{array}{l}-0.332^{*} \\
(-17.6)\end{array}$ \\
\hline Change in: & & & \\
\hline Percent Non-Alliance Direct & & $\begin{array}{l}-0.172^{*} \\
(-5.96)\end{array}$ & $\begin{array}{l}-0.190^{*} \\
(-6.37)\end{array}$ \\
\hline Percent Round Trip & & $\begin{array}{l}-0.007 \\
(-0.17)\end{array}$ & $\begin{array}{l}-0.007 \\
(-0.18)\end{array}$ \\
\hline City Pair Non-Alliance HHI & & & $\begin{array}{l}0.053^{\circ} \\
(2.82)\end{array}$ \\
\hline R-Square & 0.0008 & 0.0743 & 0.0757 \\
\hline $\mathbf{N}$ & 5,884 & 5,884 & 5,884 \\
\hline
\end{tabular}

- Statistically significant at the five percent level.

Notes: White-adjusted t-statistics reported in parentheses.

City pairs with lewer than five passengers per day are excluded.

Results are based on the 3rd quarters of 1994 and 1996.

Source: Data Base Products Inc.; Nonthwest. 
- in this specification, we find fares on the alliance pairs fell relative to the non-alliance pairs by about 4.6 percent.

The third column of Table 2 adds CHANGE IN CITY PAIR NON-ALLIANCE HHI as an explanatory variable. For the NWIAS analysis, we find that a 1000 point increase in this variable is associated with an increase in average fares of about 0.5 percent. Adding this regressor again does not substantially change the estimated alliance effect on fares (about -4.7 percent).

\section{Effect of Alliances on Traffic.}

In light of the procompetitive effect on fares of each alliance, we also would expect a procompetitive effect on output and that is indeed what we find, though the effect is statistically significant only at the 10 percent level for the NWIAS alliance. We find that the CO/HP alliance was associated with a statistically significant increase in traffic on alliance pairs. We use the same three regression specifications as reported in the previous section, substituting the change in traffic for the change in average fare as the dependent variable. See Table 3 . The first column shows that the alliance dummy-only model implies an alliance effect of 9.0 percent. Adding additional regressors (columns 2 and 3 ) reduces the estimated effect, but it remains substantial and statistically significant (over 6.5 percent). The NWIAS alliance was associated with a (statistically insignificant) increase in traffic on alliance pairs of about three percent in the alliance dummy-only model. When the other regressors are added, the estimated effect increases to about four percent, and the effect becomes statistically significant at the 10 percent level. See Table 4. 


\section{Table 3}

\section{CO/HP Base Model Results - Change in Traffic}

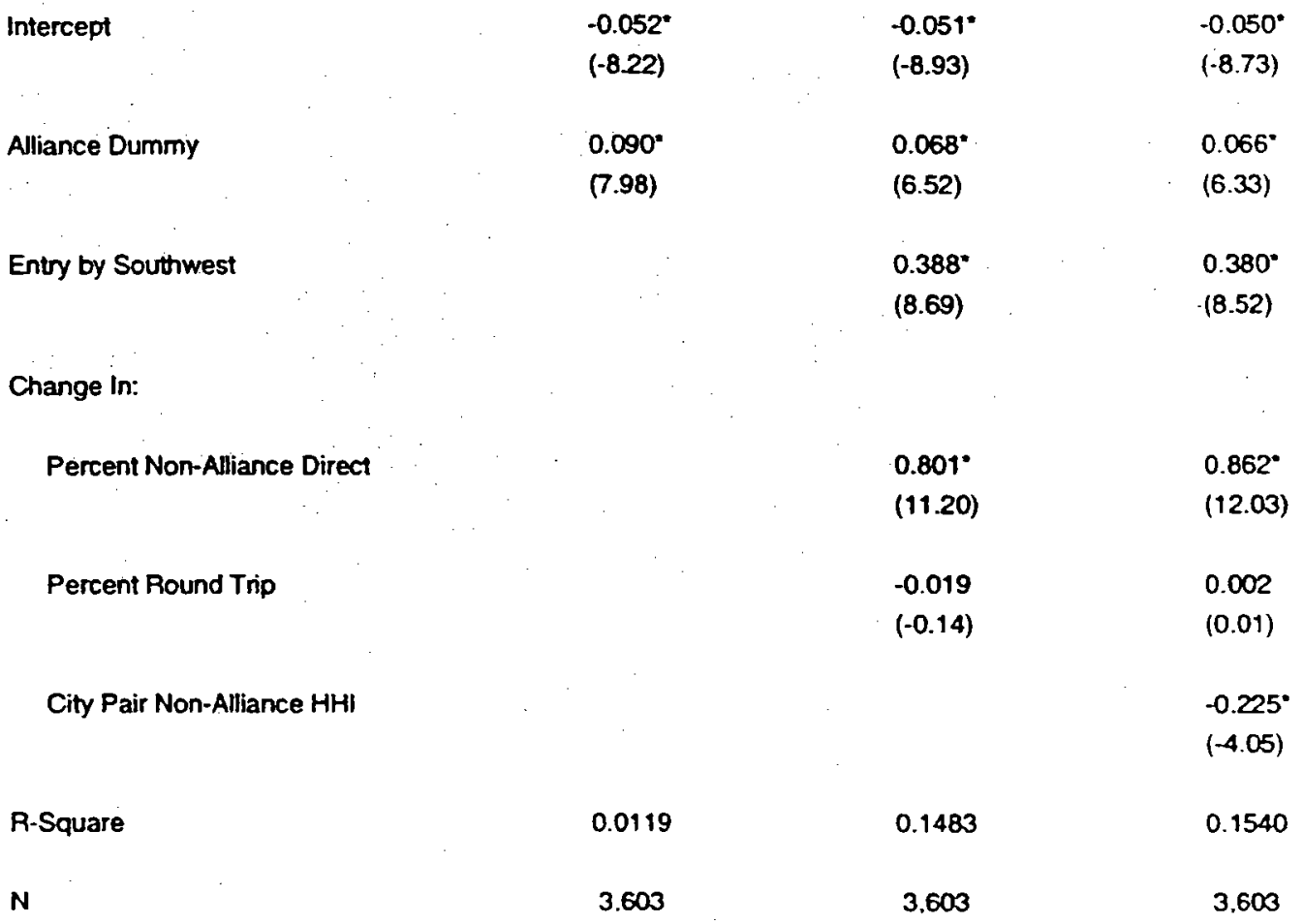

- Statistically significant at the five percent level.

Notes: White-adjusted t-statistics reported in parentheses.

City pairs with fewer than 10 passengers per day are excluded.

Results are based on the 3rd quarters of 1994 and 1995

Source: Data Base Products Inc.; Continental. 
Table 4

NWIAS Base Model Results - Change in Traffic

\begin{tabular}{|c|c|c|c|}
\hline Intercept & $\begin{array}{l}0.072^{*} \\
(14.71)\end{array}$ & $\begin{array}{l}0.053^{*} \\
(11.28)\end{array}$ & $\begin{array}{l}0.055^{\circ} \\
(11.83)\end{array}$ \\
\hline Alliance Dummy & $\begin{array}{l}0.031 \\
(1.35)\end{array}$ & $\begin{array}{l}0.040 \\
(1.79)\end{array}$ & $\begin{array}{l}0.041 \\
(1.86)\end{array}$ \\
\hline Entry by Southwest & & $\begin{array}{l}0.475^{\prime} \\
(14.30)\end{array}$ & $\begin{array}{l}0.460^{*} \\
(13.79)\end{array}$ \\
\hline Change in: & & & \\
\hline Percent Non-Aliance Direct & & $\begin{array}{l}0.746^{\circ} \\
(9.64)\end{array}$ & $\begin{array}{l}0.803^{\prime} \\
(10.64)\end{array}$ \\
\hline Percent Round Trip & & $\begin{array}{l}-0.128 \\
(-1.57)\end{array}$ & $\begin{array}{l}-0.127 \\
(-1.56)\end{array}$ \\
\hline City Pair Non-Alliance $\mathrm{HHI}$ & & & $\begin{array}{l}-0.165^{\circ} \\
(-4.52)\end{array}$ \\
\hline R-Square & 0.0002 & 0.1315 & 0.1365 \\
\hline $\mathbf{N}$ & 5.884 & 5,884 & 5,884 \\
\hline
\end{tabular}

- Statistically significant at the five percent level.

Notes: White-adjusted t-statistics reported in parentheses.

City pairs with fewer than five passengers per day are excluded.

Results are based on the 3rd quarters of 1994 and 1996.

Source: Data Base Products Inc.; Northwest. 


\section{B. Other Findings.}

\section{New Service vs. Additional Service.}

As we have discussed, a code-sharing alliance can create new online competitors on a city pair (e.g., if one partner flies A to B and the other flies $B$ to $C$, the alliance creates one or two additional online competitors on $\mathrm{A}$ to $\mathrm{C}$ ) or increase the service available from an existing online competitor (e.g., if one partner flies A to $B$ three times daily and $B$ to $C$ once daily, and the other partner flies $B$ to $C$ twice daily). We investigate the extent to which the alliance has a different effect when it creates "new service" compared to the case where it creates "additional service." We substitute the following two dummy variables for the ALLIANCE DUMMY:

(1) ALLIANCE-NEW PAIR - a dummy variable that equals one for alliance pairs if the combined share of Continental and America West is less than or equal to five percent in the third quarter of 1994; zero otherwise; and

(2) ALLIANCE-EXISTING PAIR - a dummy variable that equals one for alliance pairs if the combined share of Continental and America West is greater than five percent in the third quarter of 1994; zero otherwise.

That is, we assume that the alliance created a new online competitor on a city pair if the partners' pre-alliance share (including interlines) was less than five percent; if the partners' prealliance share exceeded five percent, we assume that one or both of the partners already offered service on that city pair prior to the alliance. ${ }^{28}$

We find that fares fell by roughly the same amount on both types of alliance pairs. We also find that traffic increased by roughly the same amount on both types of alliance pairs. See Tables 5 and 6 . F tests fail to reject the hypothesis that the coefficients on the two alliance dummies are the same in each of the fare and traffic regressions.

28. The majority of alliance pairs in our analysis are "existing" pairs. 
Table 5

New Pair vs. Existing Pair - Change in Fares

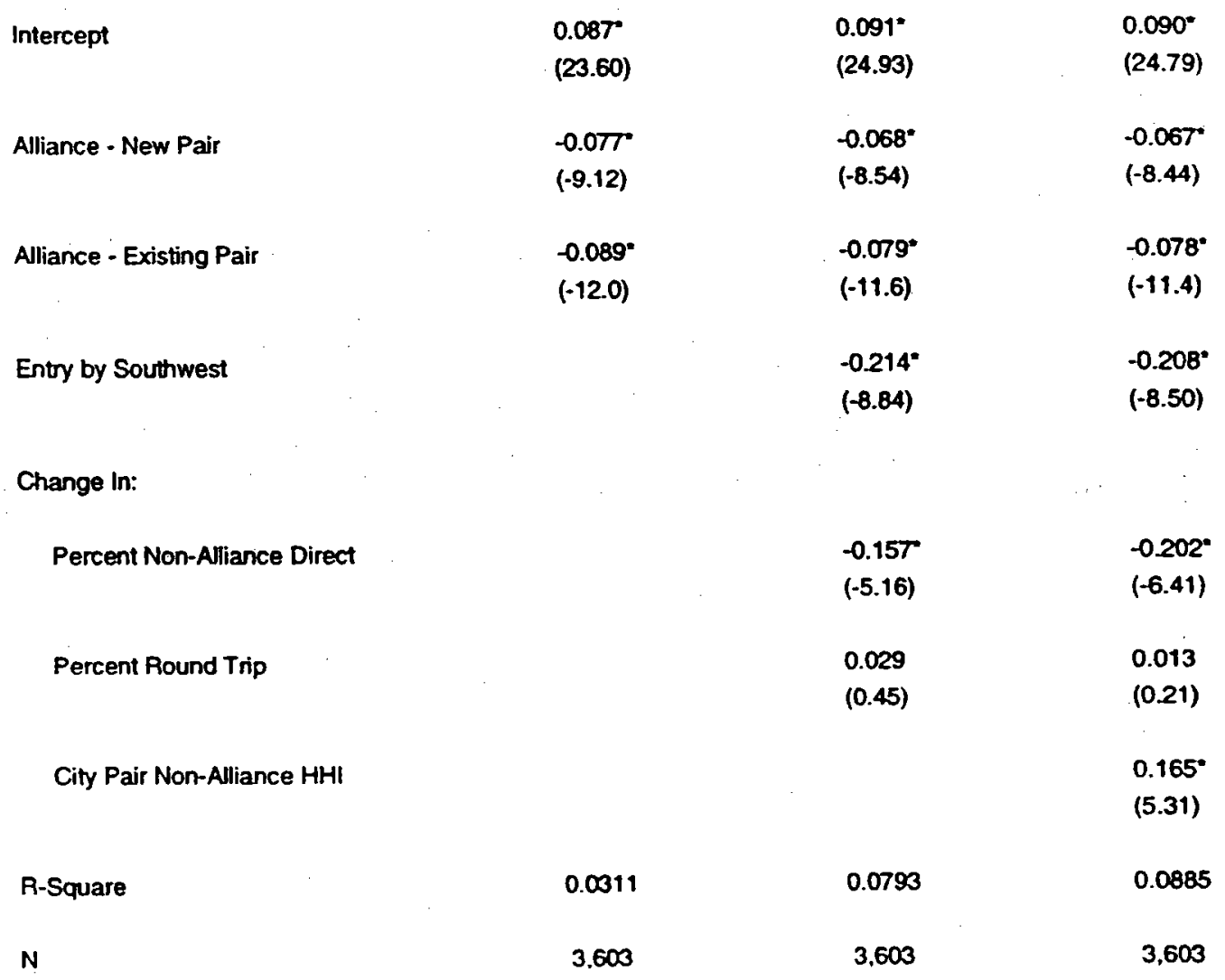

- Statistically significant at the five percent level.

Notes: White-adjusted $\mathrm{t}$-statistics reported in parentheses.

City pairs with fewer then 10 passengers per day are excluded.

Results are based on the 3rd quarters of 1994 and 1995.

Source:Data Base Products Inc.; Continental. 
Table 6

New Pair vs. Existing Pair - Change in Traffic

\begin{tabular}{|c|c|c|c|}
\hline Intercept & $-0.052^{*}$ & $-0.051^{*}$ & $-0.050^{*}$ \\
\hline & $(-8.22)$ & $(-8.93)$ & $(-8.73)$ \\
\hline Alliance - New Pair & $0.090^{\circ}$ & 0.067 & $0.065^{\circ}$ \\
\hline & $(5.33)$ & $(4.24)$ & $(4.13)$ \\
\hline Alliance - Existing Pair & $0.090^{*}$ & $0.068^{\circ}$ & $0.066^{\circ}$ \\
\hline & $(6.81)$ & $(5.59)$ & $(5.42)$ \\
\hline (a) & & & \\
\hline Entry by Southwest & & $0.388^{*}$ & $0.380^{\circ}$ \\
\hline & & $(8.68)$ & (8.52) \\
\hline Change in: & & & \\
\hline Percent Non-Alliance Direct & & $0.801^{*}$ & $0.862^{*}$ \\
\hline & & $(11.20)$ & $(12.03)$ \\
\hline Percent Round Trip & & -0.019 & 0.002 \\
\hline & & $(-0.14)$ & $(0.01)$ \\
\hline City Pair Non-Alliance $\mathrm{HHI}$ & & & $-0.225^{*}$ \\
\hline & & & $(-4.05)$ \\
\hline R-Square & 0.0119 & 0.1483 & 0.1540 \\
\hline & 3.603 & 3,603 & 3,603 \\
\hline
\end{tabular}

- Statistically significant at the five percent level.

Notes: White-adjusted t-statistics reported in parentheses.

City pairs with fewer than 10 passengers per day are excluded.

Results are based on the 3rd quarters of 1994 and 1995.

Source: Data Base Products Inc.; Continental. 


\section{Alliance Effect Varies with Level of Pre-Alliance Competition.}

In our base models, we measure one alliance effect for each alliance. That is, we do not allow the effect of the alliance to depend on the characteristics of the city pair on which the alliance operates. We now investigate the extent to which the alliance effect depends on a particular city pair characteristic - the level of pre-alliance competition on the city pair. We measure the level of pre-alliance competition on a city pair as a function of the $\mathrm{HHI}$ on that city pair in the "before" period. We allow for the effect to depend non-linearly on the pre-alliance level of competition.

We investigate the extent to which the alliance effect depends on the pre-alliance level of competition by including measures of pre-alliance concentration. In particular, we add the following regressors to our base models:

(1) ALLIANCE $\times \mathrm{HHI}$ - the alliance dummy times the pre-alliance city pair $\mathrm{HHI}$;

(2) ALLIANCE $\times$ HHI SQUARED - the alliance dummy times the squared prealliance city pair $\mathrm{HHI}$;

(3) $\mathrm{HHI}$ - the pre-alliance city pair $\mathrm{HHI}$; and

(4) HHI SQUARED - the pre-alliance city pair HHI squared.

We find that the interactions of the alliance dummy with the pre-alliance $\mathrm{HHI}$ and the prealliance $\mathrm{HHI}$ squared are statistically significant (and jointly statistically significant) in each of the three fare regressions. See Table 7. That is, we find that the alliance effect depends (nonlinearly) on the level of pre-alliance competition, as measured by the city pair $\mathrm{HHI}^{29}$ We find that the CO/HP alliance had a relatively smaller effect on city pairs that already had a large number of competitors, or were served primarily by only one carrier; the alliance had a relatively larger effect on city pairs that were served by (roughly) the equivalent of two equal-sized

29. We also find that the change in fares on non-alliance pairs depends non-linearly on the prealliance level of competition. In particular, we find that fares rose most rapidly on nonalliance pairs with HHIs of around 5,000. 
Table 7

Effect of Pre-Existing Level of Competition - Change in Fares

\begin{tabular}{|c|c|c|c|}
\hline \multirow[t]{2}{*}{ Intercept } & $-0.084^{\circ}$ & $-0.073^{\prime}$ & $-0.081^{*}$ \\
\hline & $(-3.74)$ & $(-3.32)$ & $(-3.71)$ \\
\hline \multirow[t]{2}{*}{ Alliance Dummy } & 0.038 & 0.042 & 0.047 \\
\hline & $(1.09)$ & $(1.27)$ & $(1.43)$ \\
\hline \multirow{2}{*}{ Alliance $\times \mathrm{HHI}$} & $-0.468^{\circ}$ & $-0.451^{*}$ & $-0.456^{\circ}$ \\
\hline & $(-3.03)$ & $(-3.09)$ & $(-3.12)$ \\
\hline & & & $0.403^{*}$ \\
\hline Alliance $\times$ HHI Squared & $0.7 C^{2}$ & $(2.85)$ & $(2.85)$ \\
\hline \multirow[t]{2}{*}{$\mathrm{HHI}$} & $0.639^{\circ}$ & $0.621^{\circ}$ & $0.630^{\circ}$ \\
\hline & $(7.21)$ & $(7.16)$ & $(7.29)$ \\
\hline \multirow[t]{2}{*}{ HHI Squared } & $-0.511^{*}$ & $-0.508^{*}$ & $-0.500^{*}$ \\
\hline & $(-6.72)$ & $(-6.80)$ & $(-6.72)$ \\
\hline \multirow[t]{2}{*}{ Entry by Southwest } & & $-0.211^{\circ}$ & $-0.203^{*}$ \\
\hline & & $(-8.71)$ & $(-8.30)$ \\
\hline \multicolumn{4}{|l|}{ Change In: } \\
\hline \multirow[t]{2}{*}{ Percent Non-Alliance Direct } & & $-0.149^{*}$ & $-0.194^{*}$ \\
\hline & & $(-4.99)$ & $(-6.25)$ \\
\hline \multirow[t]{2}{*}{ Percent Round Trip } & & 0.036 & 0.022 \\
\hline & & $(0.57)$ & $(0.36)$ \\
\hline \multirow[t]{2}{*}{ City Pair Non-Alliance HHI } & & & $0.179^{\circ}$ \\
\hline & & & $(5.77)$ \\
\hline R.Square & 0.0461 & 0.0926 & 0.1031 \\
\hline $\mathbf{N}$ & 3.603 & 3.603 & 3,603 \\
\hline
\end{tabular}

- Statistically significant at the five percent level.

Notes: White-adjusted t-statistics reported in parentheses.

City pairs with fewer than 10 passengers per day are excluded.

Results are based on the 3rd quarters 1994 and 1995.

Source: Data Base Products Inc.; Continental. 
competitors prior to the alliance. ${ }^{30}$ For example, out results imply that the alliance lowered average fares by eight to nine percent (depending on specification) on a route where two equalsized firms competed in the pre-alliance period, but by only about three to four percent on a route where five equal-sized firms competed in the pre-alliance period. (For the $709 \mathrm{CO} / \mathrm{HP}$ alliance pairs in our analysis, the fifth, $25^{\text {th }}, 50^{\text {th }}, 75^{\text {th }}$ and $95^{\text {th }}$ percentiles of the distribution of pre-alliance city pair HHIs are 1,$825 ; 2,504 ; 3,395 ; 4,604 ;$ and 7,409 .)

Table 8 presents our results for traffic regressions. We do not find a statistically significant relation between changes in traffic on alliance pairs and the pre-alliance level of $\mathrm{HHI}$ on those pairs in any of the three regressions - the coefficients on the two alliance dummy interaction variables are not statistically significant individually or jointly.

\section{CONCLUSION}

In this paper, we investigate empirically the effect of two recent domestic airline alliances. We find that both alliances benefited consumers - average fares fell and total traffic increased after the creation of the alliances on those city pairs affected by the alliances. We also find that these effects are found both on city pairs where the alliance created one or two new online carriers, and on city pairs where the alliance increased the service offered by one or both alliance partners. Finally, we find that the size of the fare effect of the alliance depends on the pre-alliance level of competition on a city pair with the effect being larger on those city pairs where the level of competition was relatively low.

Our empirical findings provide strong support for the view that domestic airline alliances benefit consumers and that anti-competitive concerns with such alliances are misplaced.

30. Our findings are consistent with the existence of an "S curve" relationship between price and the level of competition. See, for example, Carlton and Perloff (1999), p. 258. 
Table 8

Effect of Pre-Existing Level of Competition - Change in Traffic

\begin{tabular}{|c|c|c|c|}
\hline Intercept & $\begin{array}{l}0.146^{*} \\
(3.37)\end{array}$ & $\begin{array}{l}0.106^{*} \\
(2.62)\end{array}$ & $\begin{array}{l}0.118^{*} \\
(2.94)\end{array}$ \\
\hline Alliance Dummy & $\begin{array}{l}-0.015 \\
(-0.24)\end{array}$ & $\begin{array}{l}-0.009 \\
(-0.16)\end{array}$ & $\begin{array}{l}-0.017 \\
(-0.30)\end{array}$ \\
\hline Alliance $\times \mathrm{HHI}$ & $\begin{array}{l}0.264 \\
(0.97)\end{array}$ & $\begin{array}{l}0.209 \\
(0.82)\end{array}$ & $\begin{array}{l}0.216 \\
(0.85)\end{array}$ \\
\hline Aliance $\times$ HHI Squared & $\begin{array}{l}-0.169 \\
(-0.66)\end{array}$ & $\begin{array}{l}-0.153 \\
(-0.63)\end{array}$ & $\begin{array}{l}-0.154 \\
(-0.64)\end{array}$ \\
\hline HHI & $\begin{array}{l}-0.585 \\
(-3.33)\end{array}$ & $\begin{array}{l}-0.493^{*} \\
(-2.97)\end{array}$ & $\begin{array}{l}-0.507 \\
(-3.07)\end{array}$ \\
\hline HHI Squared & $\begin{array}{l}0.337 \\
(2.09)\end{array}$ & $\begin{array}{l}0.313^{*} \\
(2.07)\end{array}$ & $\begin{array}{l}0.301 " \\
(2.00)\end{array}$ \\
\hline Entry by Southwest & & $\begin{array}{l}0.379^{*} \\
(8.51)\end{array}$ & $\begin{array}{l}0.367 \\
(8.29)\end{array}$ \\
\hline Change in: & & & \\
\hline Percent Non-Alliance Direct & & $\begin{array}{l}0.774^{*} \\
(10.92)\end{array}$ & $\begin{array}{l}0.844^{*} \\
(11.80)\end{array}$ \\
\hline Percent Round Trip & & $\begin{array}{l}-0.041 \\
(-0.29)\end{array}$ & $\begin{array}{l}-0.020 \\
(-0.14)\end{array}$ \\
\hline City Pair Non-Alliance HHI & & & $\begin{array}{l}-0.274^{*} \\
(-4.80)\end{array}$ \\
\hline R-Square & 0.0272 & 0.1560 & 0.1642 \\
\hline $\mathbf{N}$ & 3,600 & 3,603 & 3,603 \\
\hline
\end{tabular}

- Statistically significant at the five percent level.

Notes: White-adjusted t-statistics reported in parentheses.

City pairs with fewer than 10 passengers per day are excluded.

Results are based on the 3rd quarters of 1994 and 1995.

Source: Data Base Products Inc.; Continental. 


\section{REFERENCES}

Bamberger, Gustavo and Dennis Carlton (1996), "Airline Networks and Fares," unpublished working paper.

Brueckner, Jan (1997), "The Economics of International Codesharing: An Analysis of Airline Alliances," University of Illinois at Urbana-Champaign, Office of Research Working Paper Number $97-0115$.

Brueckner, Jan and W. Tom Whalen (1998), "The Price Effects of International Alliances," December, unpublished working paper.

Carlton, Dennis, William Landes and Richard Posner (1980), "Benefits and Costs of Airline Mergers: A Case Study," Bell Journal of Economics, Spring, at 65.

Carlton, Dennis and Jeffrey Perloff, (1999) Modern Industrial Organization, 3rd ed.

Evans, Williams, Luke Froeb and Gregory Werden (1993), "Endogeneity in the ConcentrationPrice Relationship: Causes, Consequences and Cures," Journal of Industrial Economics, September, at 1.

Evans, William and loannis Kessides (1994), "Living by the "Golden Rule": Multimarket Contact in the U.S. Airline Industry," Quarterly Journal of Economics, May, at 341.

Oum, Tae, J.-H Park and A. Zhang (1996), "The Effects of Airline Codesharing Agreements on Firm Conduct and International Air Fares," Journal of Transport Economics and Policy, May, at 187.

Park, J.-H (1997), "The Effects of Airline Alliances of Markets and Economic Welfare," Logistics and Transportation Review, at 181.

U.S. Department of Transportation (1994), A Study of International Airline Code Sharing, Gellman Research Associates, Inc.

U.S. General Accounting Office (1995), Airline Alliances Produce Benefits, but Effect on Competition is Uncertain, GAO/RCED-95-99. 